\title{
Heavy metal toxicity in rice and soybean plants cultivated in contaminated soil
}

\author{
Maria Lígia de Souza Silva', Godofredo Cesar Vitti ${ }^{2}$, Anderson Ricardo Trevizam ${ }^{3}$
}

\begin{abstract}
Heavy metals can accumulate in soil and cause phytotoxicity in plants with some specific symptoms. The present study evaluated the specific symptoms on rice and soybeans plants caused by excess of heavy metals in soil. Rice and soybean were grown in pots containing soil with different levels of heavy metals. A completely randomized design was used, with four replications, using two crop species and seven sample soils with different contamination levels. Rice and soybean exhibited different responses to the high concentrations of heavy metals in the soil. Rice plants accumulated higher $\mathrm{Cu}, \mathrm{Mn}, \mathrm{Pb}$ and $\mathrm{Zn}$ concentrations and were more sensitive to high concentrations of these elements in the soil, absorbing them more easily compared to the soybean plants. However, high available $\mathrm{Zn}$ concentrations in the soil caused phytotoxicity symptoms in rice and soybean, mainly chlorosis and inhibited plant growth. Further, high $\mathrm{Zn}$ concentrations in the soil reduced the Fe concentration in the shoots of soybean and rice plants to levels considered deficient.
\end{abstract}

Key words: contamination, plant nutrition, symptomatology, heavy metals, Oriza sativa L., Glycine max L.

\section{RESUMO}

\section{Toxicidade por metais pesados em plantas de arroz e soja cultivados em solo contaminado}

Os metais pesados podem-se acumular no solo, causando fitotoxicidade em plantas, apresentando alguns sintomas específicos. Por esta razão, este estudo avaliou os sintomas específicos, em plantas de arroz e de soja, causados por excesso de metais pesados no solo. As plantas de arroz e de soja foram cultivadas em vasos, contendo solos com diferentes quantidades de metais pesados. O delineamento experimental foi inteiramente casualizado, com quatro repetições, utilizando-se duas culturas e sete amostras de solos com diferentes níveis de contaminação. As plantas de arroz e de soja exibiram diferentes respostas às elevadas concentrações desses metais no solo. Por exemplo, altas concentrações de Zn disponível no solo causaram fitotoxicidade no arroz e na soja, principalmente cloroses e inibição do crescimento das plantas. As plantas de arroz acumularam maiores teores de $\mathrm{Cu}, \mathrm{Mn}, \mathrm{Pb}$ e $\mathrm{Zn}$ e foram mais sensíveis às concentrações elevadas desses elementos no solo, absorvendo-os mais facilmente do que as plantas de soja. Além disso, altas concentrações de Zn no solo reduziram a concentração de Fe na parte aérea das plantas de soja e de arroz para níveis considerados deficientes.

Palavras-chave: contaminação, nutrição de plantas, sintomatologia, metal pesado, Oriza sativa L., Glycine max L.

\footnotetext{
${ }^{1}$ Engenheira-Agrônoma. Departamento de Agronomia, Universidade Estadual do Centro-Oeste, Rua Simeão Camargo Varela de Sá, 3, Vila Carli, 85040-080, Guarapuava, Paraná, Brasil. mlsousi@hotmail.com (autora para correspondência).

2 Engenheiro-Agrônomo. Departamento de Ciência do Solo, Escola Superior de Agricultura "Luiz de Queiroz", Avenida Pádua Dias, 11, Caixa Postal 09, 13418-900, Piracicaba, São Paulo, Brasil. gcvitti@usp.br

${ }^{3}$ Químico. Departamento de Agronomia, Universidade Estadual do Centro-Oeste, Rua Simeão Camargo Varela de Sá, 3, Vila Carli, 85040-080, Guarapuava, Paraná, Brasil. aanrt@hotmail.com
} 


\section{INTRODUCTION}

Increasingly economic growth and technological development is evident in modern times, but has brought about numerous environmental problems caused by residues derived from industrial processes. Heavy metals when applied to the soil can accumulate and persist for long periods of time. These elements can be phytotoxic and harmful to vital microbial processes in nutrient cycling (Oliveira et al., 2005).

Plants have mechanisms of tolerance to high concentrations of heavy metals. These include restricting transport from the root to the leaf, accumulation in trichomes, exudates that can complex the heavy metals, type of link between the element and the cell wall component, intracellular production of compounds with chelating properties and active pumping to the vacuoles. These mechanisms can occur individually or simultaneously, conferring increased tolerance to stress caused by the presence of heavy metals (Yadav, 2010; Hossain et al., 2012).

The processes of heavy metal absorption by plants are basically the same as those observed for macro and micronutrients. According to Carver \& Ownby (1995) this absorption generally occurs actively or passively. However, heavy metals in the soil should be primarily in exchangeable form for absorption to occur (Kabala \& Singh, 2001).

Symptoms in plants caused by shortage or excess of these elements and the associated levels in tissues make up a useful guide to establish deficiency or toxicity. It is therefore very important to know the heavy metal distribution in different parts of the plant. Some heavy metals in excess may result in toxicity to animals and crops (Gupta \& Gupta, 1998). In the study of plant nutrition, it is necessary to consider the nutrients as a whole because in the absorption process elements can influence one another. However, interactions may occur altering the mineral composition of the leaves (Raij, 1991).

According to Adriano et al. (1971) toxicity symptoms are a result of alterations in metabolic processes, but are not common in the field. However may occur in areas with high availability of heavy metals and in plants that are not tolerant to these elements. In the case of zinc ( $\mathrm{Zn})$, chlorosis may occur in younger leaves due to interference in the iron $(\mathrm{Fe})$ function in the chloroplasts and chlorophyll synthesis or decrease in root and leaf size and, when at high levels, there is decrease in phosphorus (P) and Fe absorption.

Cadmium $(\mathrm{Cd})$ can reduce growth, photosynthesis rate and cause both enzymatic and metabolic alterations (Parmar et al., 2013). Another symptom identified for this metal is the chlorosis caused by the $\mathrm{Cd}$ and $\mathrm{Fe}$ competition for absorption sites in the plasma membrane (Siedlecka \& Krupa, 1999; Tran \& Popova, 2013).

The present study evaluated the specific symptoms in rice and soybeans plants caused by excess of heavy metals in the soil.

\section{MATERIALS AND METHODS}

The soil used in the study had been accidently contaminated and presented high levels of trace elements according to the intervention values described by CETESB (2005) (Table 1). Soil samples were collected in the district of Paulínia, SP, Brazil (22 $45^{\prime}$ S, $\left.47^{\circ} 09^{\prime} \mathrm{W}\right)$ and classified as Typic Hapludox, containing $590 \mathrm{~g} \mathrm{~kg}^{-1}$ clay, $100 \mathrm{~g} \mathrm{~kg}^{-1}$ silt and $310 \mathrm{~g} \mathrm{~kg}^{-1}$ sand. Because contamination was associated with the wind, the soil was collected following the predominant direction of the wind, at equidistant points $100 \mathrm{~m}$ apart, starting from the pollution source and arranged and named as follows: Soil $1(100 \mathrm{~m})$, Soil 2 (200 m), Soil 3 (300 m), Soil 4 (400 m), Soil 5 (500 m), Soil $6(600 \mathrm{~m})$ and Soil $7(700 \mathrm{~m})$, at a depth of $0-20 \mathrm{~cm}$. Soils were air-dried, sieved ( $5 \mathrm{~mm}$ mesh) and stored. For the experiment, soil samples were placed in $5 \mathrm{dm}^{3}$ pots. Irrigation was applied so as not to exceed the maximum of $70 \%$ and minimum of $40 \%$ of the water retention capacity, by weighing the pots daily.

The experiments were conducted in a greenhouse, in Piracicaba, SP, Brazil, from November 2004 to April 2005. The plant species used in the experiment were rice (Oriza sativa L. cv. IAC 202) and soybean (Glycine max L. cv. BRS 133). Fertilization with NPK was applied according to the need of each crop (Raij et al., 1997). A randomized complete design was used, in a 7 x 2 factorial scheme ( 7 soil samples and 2 plants species), with four replications, in a total of 56 experimental units.

Ten seeds were sown in each pot on November 25, 2004 , for both rice and soybean. Three days after germination the plants were thinned to four per pot. The diagnostic leaves were collected following methodology described by Malavolta et al. (1997). For rice, the leaf Y (immediately below the newest uncoiled leaf) was collected in the middle of the tilling period, on the $50^{\text {th }}$ day after sowing. For soybean, the first mature leaf starting from the tip of the branch was collected, at the end of the flowering period (on the $69^{\text {th }}$ day after sowing). The samples were stored in paper bags and dried. Thereafter, the plants were grown until maturation and cut close to the soil surface. The collected material was washed in running water, and then rinsed in distilled water. Afterwards, they were dried in forced-air oven $\left(60-70^{\circ} \mathrm{C}\right)$, weighed and crushed in a Wiley mill.

Digestion was carried out in an open system, using a slight modification of the method described by Oliva et 
al. (2003). The concentrations of $\mathrm{Cd}, \mathrm{Cu}, \mathrm{Fe}, \mathrm{Mn}, \mathrm{Pb}$ and $\mathrm{Zn}$ in the extracts were analyzed by an inductively coupled plasma optical emission spectrometer (ICP-OES) (Miyazawa et al., 2009).

The data on the concentrations of $\mathrm{Cd}, \mathrm{Cu}, \mathrm{Fe}, \mathrm{Mn}, \mathrm{Pb}$ and $\mathrm{Zn}$ were analyzed and compared statistically by the Tukey test at $5 \%$ probability according to the methodology described by Pimentel-Gomes (1990).

\section{RESULTS AND DISCUSSION}

During cultivation, the crops had different reactions and development in response to high concentrations of heavy metals in the soil. Progressive symptoms of heavy metal toxicity appeared in the rice shoots, in young leaves. The leaves had dark green ribs in contrast to the rest of the yellow leaf. With toxicity severity, the leaves became totally chlorotic and became whitish with time, progressing to the drying of the leaf (Figure 1). In the Soil 1, with higher heavy metal concentrations (Table 1), especially $\mathrm{Zn}$, rice plants died 10 days after germination (Figure 2).

The toxicity symptoms in soybean were characterized by generalized internerval chlorosis in young leaves with the appearance of dark brown spots, progressing to the drying of the leaves (Figure 3). A reduction in plant growth was also observed (Figure 4), but the symptoms of toxicity in soybean was less intense in comparison with rice, since they were slower to be expressed. The rice plants presented toxicity as early as the first 10 days at higher concentrations of metals in the soil. The soybean plants completed the cycle in all soils.

Soares et al. (2001) observed that excess Zn reduced $\mathrm{Fe}$ translocation to shoots. The presence of $\mathrm{Zn}$ inhibits the Fe metabolism promoting the appearance of symptoms of induced Fe deficiency. In extreme cases of deficiency, there was a decrease in the chlorophyll concentrations resulting in leaves totally chlorotic, which later become white, causing accentuated delay in plant growth. Fe has

Table 1. Chemical analysis of the soils used in the cultivation of soybean and rice

\begin{tabular}{|c|c|c|c|c|c|c|c|c|}
\hline \multirow{2}{*}{ Characteristic } & \multirow{2}{*}{ Unit } & \multicolumn{7}{|c|}{ Soil samples } \\
\hline & & 1 & 2 & 3 & 4 & 5 & 6 & 7 \\
\hline${ }^{(1,2)} \mathrm{pH} \mathrm{CaCl}_{2}$ & & 5.8 & 5.8 & 5.2 & 5.5 & 5.5 & 5.3 & 5.2 \\
\hline (1) Organic matter & $\mathrm{g} \mathrm{dm}^{-3}$ & 29.8 & 36.3 & 34.4 & 37.2 & 35.4 & 36.3 & 33.5 \\
\hline (3) Cadmium & $\mathrm{mg} \mathrm{kg}^{-1}$ & 25 & 23 & 20 & 23 & 26 & 28 & 27 \\
\hline (3) Copper & $\mathrm{mg} \mathrm{kg}^{-1}$ & 272 & 141 & 115 & 121 & 144 & 166 & 153 \\
\hline (3) Iron & $\mathrm{mg} \mathrm{kg}^{-1}$ & 537 & 936 & 861 & 510 & 99 & 100 & 97 \\
\hline (3) Manganese & $\mathrm{mg} \mathrm{kg}^{-1}$ & 540 & 563 & 536 & 583 & 664 & 719 & 570 \\
\hline${ }^{(3)}$ Lead & $\mathrm{mg} \mathrm{kg}^{-1}$ & 333 & 208 & 174 & 198 & 226 & 244 & 229 \\
\hline (3) Zinc & $\mathrm{mg} \mathrm{kg}^{-1}$ & 544 & 189 & 113 & 106 & 106 & 108 & 102 \\
\hline (4) Cadmium & $\mathrm{mg} \mathrm{dm}{ }^{-3}$ & 0.61 & 0.20 & 0.11 & 0.01 & 0.01 & 0.10 & 0.01 \\
\hline (4) Copper & $\mathrm{mg} \mathrm{dm}^{-3}$ & 77 & 19 & 12 & 9 & 11 & 13 & 12 \\
\hline (4) Iron & $\mathrm{mg} \mathrm{dm}^{-3}$ & 10 & 10 & 13 & 10 & 11 & 11 & 17 \\
\hline (4) Manganese & $\mathrm{mg} \mathrm{dm}^{-3}$ & 38 & 64 & 77 & 59 & 67 & 84 & 51 \\
\hline (4) Lead & $\mathrm{mg} \mathrm{dm}^{-3}$ & 73 & 17 & 12 & 8 & 11 & 13 & 11 \\
\hline (4) Zinc & $\mathrm{mg} \mathrm{dm}{ }^{-3}$ & 256 & 62 & 28 & 14 & 9 & 7 & 3 \\
\hline
\end{tabular}

(1) Raij et al. (2001); (2) $\mathrm{pH}$ in calcium chloride $0,01 \mathrm{~mol} \mathrm{~L}^{-1}$; (3) Total concentration in soil, according Nieuwenhuize et al. (1991); (4) Extraction by DTPA pH 7.3, according Abreu \& Andrade (2001).

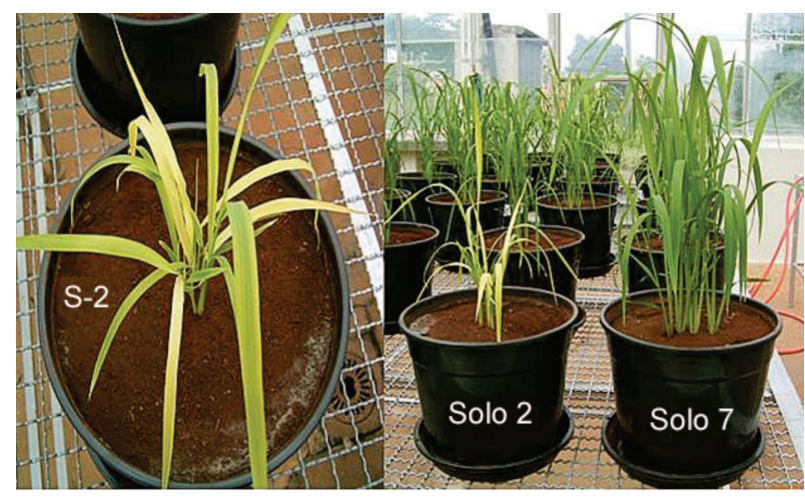

Figure 1. Characteristics of chlorotic leaves as a function of phytotoxicity by heavy metals in rice plants.

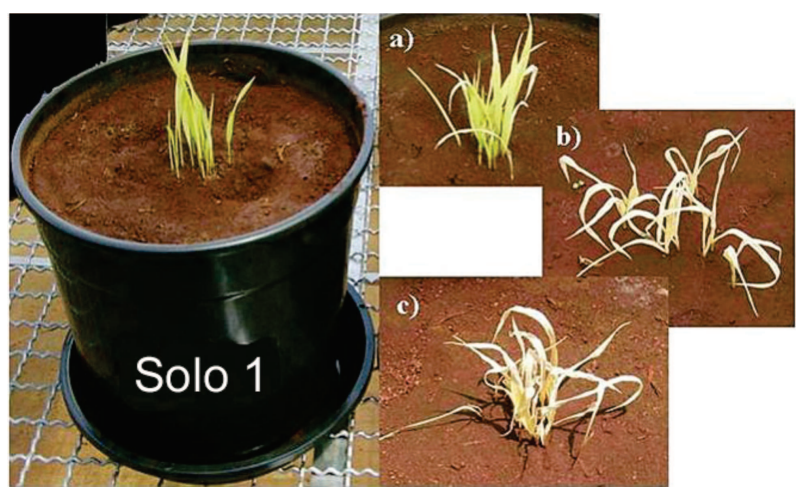

Figure 2. Phytotoxicity symptoms from a to c, evolving to death of the plants 10 days after planting. 


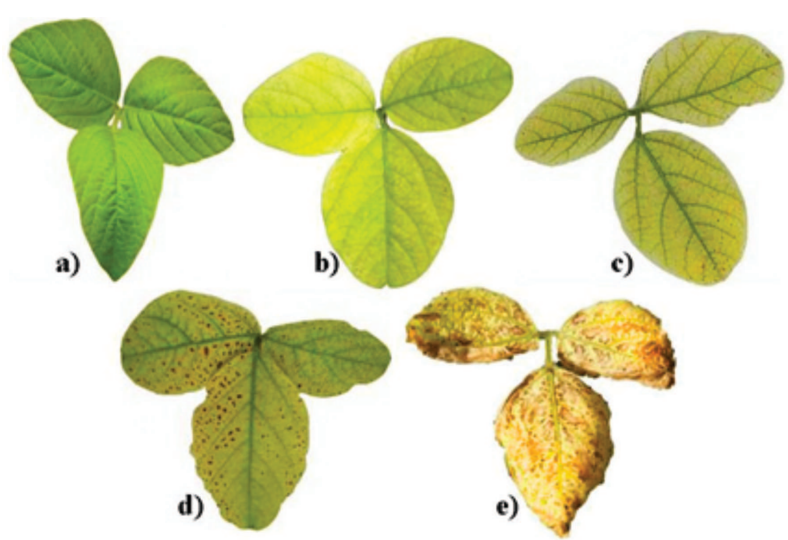

Figure 3. Evolution (25 days) of increased symptoms on soybean leaves (a, b, c, d and e).

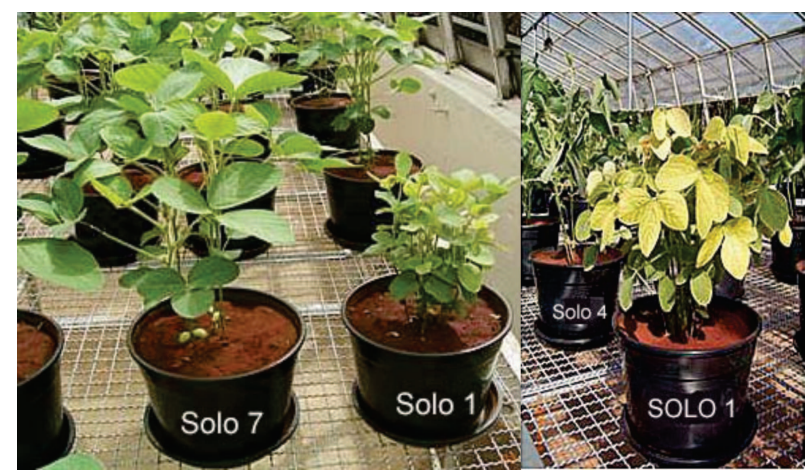

Figure 4. Difference in growth between the plants in the most contaminated soil (Soil 1) and less contaminated (Soil 7), sixty days after the seeding. numerous physiological functions in plants, but, for the expression of visual symptoms, its involvement in chloroplast formation and porphyrin synthesis are the most important processes (Romheld, 2001). One explanation for excess $\mathrm{Zn}$ causing Fe deficiency is that the ionic radii of zinc and iron happen to be nearly identical (Woolhouse, 1983; Romheld, 2001). In this work, the visual symptoms observed (Figure 1 and 3) demonstrated the interference of the $\mathrm{Zn}$ in the Fe metabolism, which is confirmed by the higher $\mathrm{Zn}$ concentration in relation to the Fe concentration (Table 2 and 3 ).

According to Mengel \& Kirkby (2001), Alloway (2008) and Ai-Qing et al. (2011) high $\mathrm{Cu}, \mathrm{Mn}$ and $\mathrm{Zn}$ concentrations can induce Fe deficiency in plants. In this study, it was observed that $\mathrm{Zn}, \mathrm{Cu}$ and $\mathrm{Cd}$, to a lesser extent, (Table 1) may have induced Fe loss in the plants. $\mathrm{Cd}$ competes with $\mathrm{Fe}$ for absorption sites in the plasma membrane (Siedlecka \& Krupa, 1999; Tran \& Popova, 2013). Excess Zn (Table 1) can cause the induced Fe loss. The presence of $\mathrm{Zn}$ inhibits the metabolism of Fe, causing the appearance of symptoms of induced Fe deficiency, which in severe cases is characterized by decreased chlorophyll levels, resulting in totally chlorotic leaves (Romheld, 2001; Izaguirre-Mayoral \& Sinclair, 2005; Ghasemi-Fasaei \& Ronaghi, 2008).

Cadmium is also responsible for absorption sites in the plasma membrane with Fe, causing Fe deficiency symptoms (Gallego et al., 1996; Siedlecka \& Krupa, 1999;

Table 2. Concentration of cadmium, copper, iron, manganese, lead and zinc in rice leaves

\begin{tabular}{|c|c|c|c|c|c|c|}
\hline \multirow{2}{*}{ Soil } & Cadmium & Copper & Iron & Manganese & Lead & \multirow{2}{*}{ Zinc } \\
\hline & & & $\mathrm{mg} \mathrm{kg}^{-1}$ & & & \\
\hline 1 & 4.86a* & $316.6 a$ & $840.9 a$ & $294.1 \mathrm{c}$ & $322.5 a$ & $2562.1 \mathrm{a}$ \\
\hline 2 & $0.87 \mathrm{~b}$ & $26.7 b$ & $63.7 \mathrm{~d}$ & $397.8 \mathrm{c}$ & $20.1 b$ & $543.1 \mathrm{~b}$ \\
\hline 3 & $0.59 \mathrm{c}$ & $22.2 \mathrm{~cd}$ & $82.5 \mathrm{~cd}$ & $388.9 \mathrm{c}$ & $17.4 \mathrm{bc}$ & $386.5 \mathrm{c}$ \\
\hline 4 & $0.25 \mathrm{de}$ & $18.2 \mathrm{e}$ & $104.6 \mathrm{c}$ & $342.5 \mathrm{c}$ & $13.8 \mathrm{~d}$ & $145.3 \mathrm{~d}$ \\
\hline 5 & $0.36 \mathrm{~d}$ & 20.6de & $93.2 \mathrm{~cd}$ & $800.5 b c$ & $15.6 \mathrm{~cd}$ & $119.4 \mathrm{de}$ \\
\hline 6 & $0.22 \mathrm{e}$ & $20.9 \mathrm{cde}$ & $92.6 \mathrm{~cd}$ & $1085.8 b$ & $15.6 \mathrm{~cd}$ & $108.4 d e$ \\
\hline 7 & $0.28 \mathrm{de}$ & $24.2 \mathrm{bc}$ & $273.7 \mathrm{~b}$ & $2540.7 \mathrm{a}$ & $19.5 b$ & $94.2 \mathrm{e}$ \\
\hline
\end{tabular}

*Means followed by the same letters in the columns are not significantly different (Tukey test, $\mathrm{p} \leq 0.05$ ).

Table 3. Concentrations of cadmium, copper, iron, manganese, lead and zinc in soybean leaves

\begin{tabular}{|c|c|c|c|c|c|c|}
\hline \multirow{2}{*}{ Soil } & Cadmium & Copper & Iron & Manganese & Lead & \multirow{2}{*}{ Zinc } \\
\hline & & & $\mathrm{mg} \mathrm{kg}^{-1}$ & & & \\
\hline 1 & $1.50 \mathrm{a} *$ & $12.1 \mathrm{a}$ & $33.8 \mathrm{~cd}$ & $99.2 \mathrm{~cd}$ & $9.4 \mathrm{a}$ & $599.6 a$ \\
\hline 2 & $0.22 \mathrm{c}$ & $9.5 \mathrm{ab}$ & $56.7 \mathrm{a}$ & $86.2 \mathrm{cde}$ & $6.5 b$ & $152.4 b$ \\
\hline 3 & $0.24 \mathrm{c}$ & $8.9 b$ & 47.3ab & $133.9 b$ & $5.4 \mathrm{c}$ & $157.9 \mathrm{~b}$ \\
\hline 4 & $0.42 b$ & $7.5 b$ & 45.1abc & $70.8 \mathrm{e}$ & $3.9 \mathrm{~d}$ & $68.2 c$ \\
\hline 5 & $0.36 \mathrm{~b}$ & $7.1 b$ & $28.8 \mathrm{~d}$ & 73.7de & $3.1 \mathrm{~d}$ & $55.2 \mathrm{c}$ \\
\hline 6 & $0.03 \mathrm{~d}$ & $8.5 b$ & $43.6 \mathrm{abc}$ & $105.1 \mathrm{c}$ & $3.5 \mathrm{~d}$ & $59.9 c$ \\
\hline 7 & $0.32 b c$ & $8.2 b$ & $38.7 \mathrm{bcd}$ & $327.7 \mathrm{a}$ & $4.1 \mathrm{~d}$ & $81.8 \mathrm{c}$ \\
\hline
\end{tabular}

*Means followed by the same letters in the columns are not significantly different (Tukey test, $\mathrm{p} \leq 0.05$ ). 
Astolfi et al., 2012). High Mn concentrations may reduce Fe absorption and induce deficiency. The Fe: Mn ratio must be maintained between 1.5 and 2.5 (Adriano, 1986), which did not occur in this case, where the ratio was below 0.7 , except for the leaves of rice in soil 1. Increasing $\mathrm{Zn}$ rates in the soil (Table 1) produced an increase in the $\mathrm{Mn}$ concentration and $\mathrm{Fe}$ reduction in the leaves.

With this information, it is assumed that the observed symptoms are indeed induced deficiency of Fe, since the soil in question has available high concentrations of $\mathrm{Cd}$, Mn and $\mathrm{Zn}$.

The contents found in standard leaves of rice according to Malavolta et al. (1997) are between the ranges of 10-20, 200-300, 100-150 and 25-35 mg kg-1 for $\mathrm{Cu}$, $\mathrm{Fe}, \mathrm{Mn}$ and $\mathrm{Zn}$, respectively. For soybean the standard leaves are between the ranges of 10-30, 51-350, 20-100 and 21-50 $\mathrm{mg} \mathrm{kg}^{-1}$ for $\mathrm{Cu}, \mathrm{Fe}, \mathrm{Mn}$ and $\mathrm{Zn}$, respectively (Malavolta et al., 1997). As for $\mathrm{Cd}$ and $\mathrm{Pb}$, the concentrations considered as normal in plants are between 0.1 and 2.4 (Bowen, 1979) and 2 and $3 \mathrm{mg} \mathrm{kg}^{-1}$ (Mengel \& Kirkby, 2001), respectively.

The critical toxicity concentration in plant leaves can range from 100 to $400 \mathrm{mg} \mathrm{kg}^{-1}$ for $\mathrm{Zn}$ (Kabata-Pendias \& Pendias, 2001) and above $600 \mathrm{mg} \mathrm{kg}^{-1}$ for Mn (Borkert et al., 2001). In soybean leaves concentrations considered toxic are above $140 \mathrm{mg} \mathrm{kg}^{-1}$ for $\mathrm{Zn}$ (Borkert et al., 1998) and $150 \mathrm{mg} \mathrm{kg}^{-1}$ for Mn (Borkert et al., 2001). Without specifying the crop, the critical toxicity concentrations in leaves can range from 3 to $8 \mathrm{mg} \mathrm{kg}^{-1}$ for Cd (Kabata-Pendias \& Pendias, 2001), up to $30 \mathrm{mg} \mathrm{kg}^{-1}$ for $\mathrm{Cu}$ (Malavolta et al., 1997; Romheld \& Marschner, 1991) and above $10 \mathrm{mg}$ $\mathrm{kg}^{-1}$ for $\mathrm{Pb}$ (Sauerbeck \& Tietz, 1983).

In relation to the ranges previously mentioned, the $\mathrm{Cu}$ concentration in rice was at toxic level in Soil 1, above 30 $\mathrm{mg} \mathrm{kg}^{-1}$. The concentration of Mn was above $150 \mathrm{mg} \mathrm{kg}^{-1}$ in all soils, but both rice and soybean presented $\mathrm{Mn}$ in this concentration only in Soil 7. The soils 1, 2, 3 and 4 for rice and 1, 2 and 3 for soybean showed $\mathrm{Zn}$ concentrations above $140 \mathrm{mg} \mathrm{kg}^{-1}$, considered as toxic. Cd concentration was found only within the range $3-8 \mathrm{mg} \mathrm{kg}^{-1}$ in Soil 1 for rice. $\mathrm{Pb}$ concentrations were up to $10 \mathrm{~m} \mathrm{~kg}^{-1}$ in all soils with rice.

The differences in absorption of the elements may be due to soil characteristics, such as interaction with organic matter, interaction between the elements, chemical immobilization of elements, among other factors that were not in the scope of this study.

According to Malavolta et al. (1997) and Ai-Qing et al. (2011), in chlorotic leaves, the total Fe content may be higher or at least equal to that found in normal leaves. Data such as these suggest that in the deficient plants, part of Fe is inactivated. In this case, it is suggested to determine the "active Fe" and not the "total Fe", which was not possible to do in this experiment, given the small amount of material produced. However, for the soybean leaves (Table 3), it is noted that, except in the treatment 2, all Fe concentrations are under the adequate concentration, but only treatment 1 presented visible signs of deficiency.

Nevertheless, the results found in rice leaves (Table 2) showed that the Fe concentration $\left(841 \mathrm{mg} \mathrm{kg}^{-1}\right)$ was far above the maximum adequate concentration (300 $\mathrm{mg} \mathrm{kg}^{-}$ ${ }^{1}$ ), which is because the leaf analysis determines the total of the elements.

In Soil 1 (Table 2), it was observed that for rice, the elements were evaluated in the range of toxic concentrations, except Mn, which was in agreement with the observed symptoms, since the plant died 10 days after germination (Figure 2). The concentrations of $\mathrm{Mn}$ in the Soils 5, 6 and 7 could have caused the appearance of toxicity symptoms, but this has not occurred in the plants.

With respect to Mn in Soils 5, 6 and 7 (800, 1086 and $2541 \mathrm{mg} \mathrm{kg}^{-1}$, respectively), for rice, several factors may have inhibited the development of Mn toxicity symptoms, such as high concentrations of $\mathrm{Fe}, \mathrm{Cu}$ and $\mathrm{Zn}$ (Pearson et $a l ., 2008)$ and the temperature. According to Gonzalez et al. (1998), temperatures above $30^{\circ} \mathrm{C}$ reduce the toxicity intensity and effect of manganese.

The high $\mathrm{Zn}$ concentration in the soil possibly interfered with the $\mathrm{Cu}$ absorption by soybean, since according to Alloway (1993) $\mathrm{Zn}^{+2}$ high activities in the soil solution have an antagonistic effect on $\mathrm{Cu}^{+2}$ absorption.

It was observed that the Mn content in Soil 1 was toxic. Phytotoxicity symptoms have been associated with $\mathrm{Mn}$ in the leaves above $600 \mathrm{mg} \mathrm{kg}^{-1}$ for rice and above 150 $\mathrm{mg} \mathrm{kg}^{-1}$ for soybean (Borkert et al., 2001). However, according to Rosolem et al. (2001), this is not a good indication of toxicity, because good soybean yields have been obtained with concentration above $200 \mathrm{mg} \mathrm{kg}^{-1}$. This occurs because the symptom manifestation depends on other factors, as already mentioned for rice.

For soybean, $\mathrm{Pb}$ and $\mathrm{Zn}$ were above the concentrations considered adequate, however, only $\mathrm{Zn}$ in the treatments 1, 2 and 3 showed toxic concentrations. In the case of Fe, all soils had concentrations below adequate, indicating a possible deficiency of this element. The other elements, $\mathrm{Cu}$ and $\mathrm{Mn}$, generally showed adequate concentrations (Table 3).

$\mathrm{Zn}$ was the most absorbed element, which most influenced the appearance of symptoms of toxicity in both Soils 1 and 2 and in both crops evaluated (Figure 1 to 4). Several authors found similar symptoms in guava plants (Salvador et al., 1999) and tropical tree species (Soares et al., 2001) under conditions of excess elements in the soil. 


\section{CONCLUSIONS}

The soybean and rice crops were shown to be sensitive to high levels of heavy metals available in the soil, exhibiting phytotoxicity symptoms manifested principally as chlorosis and inhibited plant growth.

$\mathrm{Cu}, \mathrm{Mn}, \mathrm{Pb}$ and $\mathrm{Zn}$ were higher in rice than in soybean. Rice proved to be more sensitive to high heavy metal concentrations in soil, absorbing them more easily than soybean.

High concentration of $\mathrm{Zn}$ reduced the Fe concentrations in the soybean and rice shoots to levels considered deficient, interfering with the crop development.

\section{REFERENCES}

Abreu CA \& Andrade JC (2001) 'Determinação de cobre, ferro, manganês, zinco, cádmio, cromo, níquel e chumbo em solos usando a solução de DTPA em pH 7,3'. In: Raij B van, Andrade JC, Cantarella H \& Quaggio JA (Eds.) Analise química para avaliação da fertilidade de solos tropicais. Campinas, Instituto Agronômico. p.240-250.

Adriano DC (1986) Trace Elements in the Terrestrial Environment. New York, Springer-Verlag. 533p

Adriano DC, Paulsen GM \& Murphy LS (1971) 'Phosphorus-iron and phosphorus-zinc relationship in corn (Zea mays L.) seedlings as affected by mineral nutrition'. Agronomy Journal, 63:36-39

Ai-Qing Z, Qiong-Li B, Xiao-Hong T, Xin-Chun L \& Gale WJ (2011) 'Combined effect of iron and zinc on micronutrient levels in wheat (Triticum aestivum L.)'. Journal Environmental Biology, 32:235-239.

Alloway BJ (1993) Heavy metals in soils. John Wiley, New York. $339 \mathrm{p}$.

Alloway BJ (2008) Zinc in oils and crop nutrition. Brussels, IZA and IFA Press $135 \mathrm{p}$.

Astolfi S, Zuchi S, Neumann G, Cesco S, Sanita di Toppi L \& Pinton R (2012) 'Response of barley plants to Fe deficiency and $\mathrm{Cd}$ contamination as affected by $\mathrm{S}$ starvation'. Journal of Experimental Botany, 63:1241-1250.

Borkert CM, Cox FR \& Tucker MR (1998) Zinc and cooper toxicity in peanut, soybean, rice and corn in soil mixtures. Communication Soil Science and Plant Analysis, 29:2991-3005.

Borkert CM, Pavan MA \& Bataglia OC (2001) 'Disponibilidade e avaliação de elementos catiônicos: ferro e manganês'. In: Ferreira ME (Ed.) Micronutrientes e elementos tóxicos na agricultura. Jaboticabal, CNPQ/FAPESP/POTAFOS. p.151-185.

Bowen HJM (1979) Environmental chemistry of elements. London, Academic Press. 333p.

Carver BF \& Ownby JD (1995) 'Acid soil tolerance in wheat'. Advances in Agronomy, 54:117-173.

CETESB - Companhia de Tecnologia e Saneamento Ambiental (2005) Decisão de diretoria $\mathrm{N}^{\circ}$. 195-2005-E. Valores orientadores para solos e águas subterrâneas no estado de São Paulo. Disponível em: <http://www.cetesb.sp.gov.br> Acessado em: 30 de novembro de 2011.

Gallego SM, Benavides MP \& Tomaro ML (1996) 'Effect of heavy metal ion excess on sunflower leaves: evidence for involvement of oxidative stress'. Plant Science, 12:151-159.
Ghasemi-Fasaei R \& Ronaghi A (2008) 'Interaction of iron with copper, zinc and manganese in wheat as affected by iron and manganese in a calcareous soil'. Journal of Plant Nutrition, 31:839-848.

Gonzalez A, Steffen KL \& Lynch JP (1998) 'Light and Excess Manganese. Plant Physiology’, 118:493-504.

Gupta UC \& Gupta SC (1998) 'Trace element toxicity relationship to crop production and livestock and human health: implications for management'. Communications in Soil Science and Plant Analysis, 29:1491-1522.

Hossain MA, Piyatida P, Silva JAT \& Fujita M (2012) 'Molecular mechanism of heavy metal toxicity and tolerance in plants: central role of glutathione in detoxification of reactive oxygen species and methylglyoxal and in heavy metal chelation'. Journal of Botany, Volume 2012, Article ID 872875, 37 pages. DOI: $10.1155 / 2012 / 872875$

Izaguirre-Mayoral ML \& Sinclair TR (2005) 'Soybean genotypic difference in growth, nutrient accumulation and ultrastructure in response to manganese and iron supply in solution culture'. Annals of Botany, 96:149-158.

Kabata-Pendias A \& Pendias H (2001) Trace elements in soil and plants. $3^{\mathrm{a}}$ ed. Boca Raton, CRC Press. 413p.

Cezary Kabala C \& Singh BR (2001) 'Fractionation and mobility of copper, lead, and zinc in soil profiles in the vicinity of a copper smelter'. Journal Environmental Quality, 30:485-492.

Malavolta E, Vitti GC \& Oliveira SA (1997) Avaliação do estado nutricional das plantas: princípios e aplicações. $2^{\mathrm{a}}$ ed. Piracicaba, POTAFOS. 319p.

Mengel K \& Kirkby E (2001) Principles of plant nutrition. 5 a ed. Dordrecht/Boston/London, Kluwer Academic Publishers. 849p.

Miyazawa M, Pavan MA, Muraoka T, Carmo CAFS \& Melo WJ (2009) Análise química de tecido vegetal. In: Silva FC (Ed.) Manual de análises químicas de solos, plantas e fertilizantes. Brasília, EMBRAPA. p.192-233.

Nieuwenhuize J, Poley-Vos CH, Akker AH van den \& Delft W van (1991) 'Comparison of microwave and conventional extraction techniques for the determinations of metals in soil, sediment and sludge sample by atomic spectrometry'. The Analyst, 116:347-351

Oliva SR, Raitio H \& Mingorance MD (2003) 'Comparison of two wet digestion procedures for multi-element analysis of plant samples'. Communications in Soil Science and Plant Analysis, 34:2913-2923.

Oliveira C, Amaral Sobrinho NMB, Marques VS \& Mazur N (2005) 'Efeitos da aplicação do lodo de esgoto enriquecido com cádmio e zinco na cultura do arroz'. Revista Brasileira de Ciência do Solo, 29:109-116.

Parmar P, Kumari N \& Sharma V (2013) 'Structural and functional alterations in photosynthetic apparatus of plants under cadmium stress'. Botanical Studies, 54:45-51.

Pearson JN, Rengel Z, Jenner CF \& Graham RD (2008) 'Manipulation of xylem transport affects $\mathrm{Zn}$ and Mn transport into developing wheat grains of cultured ears'. Physiology Plant, 98:229-234.

Pimentel-Gomes F (1990) Curso de Estatística Experimental. Piracicaba, Nobel. 468p.

Raij B van (1991) Fertilidade do solo e adubação. Piracicaba, Agronômica Ceres/POTAFOS. 343p.

Raij B van, Cantarella H, Quaggio JA \& Furlani AMC (1997) Recomendações de adubação e calagem para o Estado de São Paulo. 2a ed. Campinas, Instituto Agronômico. 285p. 
Raij B van, Andrade JC, Cantarella H \& Quaggio JA (2001) Análise química para avaliação da fertilidade de solos tropicais. Campinas, Instituto Agronômico. 284p.

Romheld V (2001) 'Aspectos fisiológicos dos sintomas de deficiência e toxicidade de micronutrientes e elementos tóxicos em plantas superiores'. In: Ferreira ME (Ed.) Micronutrientes e elementos tóxicos na agricultura". Jaboticabal, CNPQ/FAPESP/ POTAFOS. p.71-85.

Romheld V \& Marschner H (1991) Function of micronutrients in plant. In: Mortvedt JJ, Cox FR, Shuman LM \& Welch RM (Eds.) Micronutrients in agriculture. Madison, Soil Science Society of America. p.297-328.

Rosolem CA, Quaggio JA \& Silva NM (2001) 'Algodão, amendoim e soja'. In: Ferreira ME. (Ed.) Micronutrientes e elementos tóxicos na agricultura". Jaboticabal, CNPq/FAPESP/POTAFOS. p.319-354

Salvador JO; Moreira A \& Muraoka T (1999) 'Sintomas visuais de deficiências de micronutrientes e composição mineral de folhas em mudas de goiabeira'. Pesquisa Agropecuária Brasileira, $34: 1655-1662$
Sauerbeck DR \& Tietz E (1983) 'Soil-chemical evaluation of different extractants for heavy metals in soil'. In: Davies RD et al. (Eds.) Environmental effects of organic and inorganic contaminants in sewage sludge. Dordrecht, Reidel Publishing Company. p.147-160.

Siedlecka A \& Krupa Z (1999) ' Cd/Fe interactions in higher plants - Its consequences for the photosyntetic apparatus'. Photosynthesis Research, 36:321-331.

Soares CRFS, Grazziotti PH, Siqueira JO, Carvalho JG \& Moreira FMS (2001) 'Toxidez de zinco no crescimento e nutrição de Eucalyptus maculata e Eucalyptus urophylla em solução nutritiva'. Pesquisa Agropecuária Brasileira, 36:339-348.

Tran TA \& Popova LP (2013) 'Functions and toxicity of cadmium in plants: recent advances and future prospects'. Turkish Journal of Botany, 37:01-13

Woolhouse HW (1983) 'Toxicity and tolerance in the responses of plant to metals'. In: Lange OL et al (Eds.) Encyclopedia of plant physiology. Berlin, Springer. p.245-300.

Yadav SK (2010) 'Heavy metals toxicity in plants: An overview on the role of glutathione and phytochelatins in heavy metal stress tolerance of plants'. South African Journal of Botany, 76:167-179. 